\title{
CONSTITUTIONAL APPEAL - HUMAN RIGHTS PROTECTION PROCEDURE -with particular reference to the constitutional complaint in the Republic of Macedonia-
}

UDK: 342 (497.7) 341.231. 14

Primljeno: 1.04. 2018.

Pregledni znanstveni rad

In this text, the author examines the historical aspects of constitutional complaint, analyzes the genesis of its implementation in legal systems, firstly, in the states representing Western democracies. Furthermore, it seeks to answer the question of whether constitutional complaint is properly detected as a legal remedy or a remedy. It should be borne in mind that the definitive definition arises and is ultimately determined by the position of the constitutional court in the system of state power. Special attention is paid to the attempt to implement constitutional complaint and the legal order of the Republic of Macedonia. The author, through a brief review, carries out a critical analysis of the constituent elements of constitutional complaint that the new one predicts Draft amendment to amend the Constitution of the Republic of Macedonia. Particular attention is drawn to paragraphs 2 and 3 of the Draft Amendment XXXIX from the aspect of the negative impact they have on the position of the Constitutional Court, displacing it from the primary base with implementation and regular appeal.

Keywords: constitutional complaint, legal remedy, legal remedy, amendment to the Constitution, regular appeal.

\section{INTRODUCTION}

In contemporary democracies, the basic principle underlying the existence of a legal order is respect for the principle of supremacy of the constitution. Hence, if one takes into account the fact that the modern constitutions deviate a significant part of its content on a charter for individual and collective (human) rights, then it is clear that the protection of the constitutional order expressed by taking specific legal steps, including the protection of human rights, is not possible. Thus, the tragic events that engulfed Europe during World War II with mass and legalized violations of human rights to the extent that the civilized world had not seen before, was an impetus to the foundations of the ruined Europe to start with a different concept

\footnotetext{
*PhD candidate, "Iustinianus Primus" Faculty of law, -Skopje, e-mail: saveskidejan@yahoo.com
} 
that is defined as a new model of accepted values for the appearance of interstate cooperation, especially expressed in the field of human rights protection, which transfers its reflection at the national level. It is in this postwar period, in a modern sense, that a constitutional complaint appears as a procedural mechanism.

The name of the constitutional complaint is the work of the German theorist Seidel, and it is due to the fact that the subjects that provide protection and the objects of protection ... ${ }^{1}$ are of a purely constitutional character. Although today constitutional theory has developed a representative set of terms used for this process institute, some states have accepted to call it a constitutional complaint (Croatia, Slovenia), other constitutional appeals $(\mathrm{BiH})$, and others, amparo appeal. (Spain, Mexico, Philippines), however, seems to be the most widespread terminological coinage created by the German theorist, a constitutional complaint.

\section{HISTORICAL DEVELOPMENT}

Despite the clear time-out finding of the source of the term constitutional complaint, however, the roots of procedural protection of subjective rights violated in an objective way should be sought for centuries. Namely, in this part of the historical beginnings in legal science there is no unified position. While the majority of constitutional law scientists agree that the constitutional complaint draws its existence from the archaic model of the paternal right embodied in the recurso de amparo system in the medieval kingdom of Aragon, a minority of authors disagree with this attitude, those beginnings of this law institute has been looking for them for several years back, in the first Charter of 1215 (Magna carta libertatum). However, regardless of which of the two points mentioned at the beginning of the constitutional complaint will be accepted as an emergent basis, it is one of the oldest legal institutes in the field of human rights which provides a basic and rudimentary form of procedural law reaching the protection of individual rights in the Middle Ages. Additionally, regardless of which time period will be accepted as the starting point for the appearance of a constitutional complaint, one thing is certain, in both cases it is not about actio popularis. Access to the popular complaint was severely limited, privileged individual law was only available to the higher social class.

The breakthrough from the west to the east of the constitutional complaint, in a more complex content of its process form, is noticeable in the second decade of the nineteenth century in the Constitution of Bavaria. If the archaic model of the constitutional complaint was established as a procedural institute available only to a selected group of private law subjects, then the Bavarian conception certainly exceeds its comprehensibility, further enhancing it with elements that cross the boundaries of private law. Namely, Art. 21 item 7 of the Bavarian Constitution provided a broad basis for availability, transforming the constitutional complaint

1 Vukćević, M.; Ćupić, D., Uvod u ljudski prava, Univerizitet Mediterana Podgorica, Podgorica, 2013., p. 124. 
for the first time since its appearance as an actio popularis legal remedy. Every citizen whose constitutional rights have been violated or endangered in any way by an act adopted by an authority representing public authority has the right to seek protection. Elements that upgrade its substrate by overcoming private law everything with a public-legal character. In that sense, the constitutional complaint was available not only to natural persons, but also to municipalities, local public authorities, which have the right to call on an identical legal basis as well as natural persons, when the granted organs are endangered by the granted constitutional authorizations. Furthermore, a few years later, in 1848, Switzerland, in its first Constitution, named the state-owned legal action. The established practice continues in the second Constitution of 1874. It was followed by the state of Frankfurt in 1848, then Austria under the title state-law appeal with the highest law of the state in 1867, with limited capacity to protect only political rights. From institutionalization of the constitutional complaint Austria did not give up either in 1920, nor in 1945. It follows the Spanish amparo system in 1921, but with a relatively short-lived practice until 1939, which was re-renewed during the democratization in the 1970s.

In the period after World War II, Germany decided as a second-instance legal creation placed in secondary national law to begin the legal existence of a constitutional complaint, which was elevated to the highest hierarchical level through the constitutional intervention of the Basic Law until 1969. Moreover, from a historical point of view, if one can conclude that the Bavarian model of constitutional complaint determines Germany as the first European state for the out-of-court approach to the protection of constitutional rights, and given that the one-size decision was granted by rule to any of the two parliamentary houses, and with the exception of the King, then it can safely be noted that Switzerland is a beginner of the judicial protection of constitutional rights.

From the wave of prescribing a procedural mechanism available to the private entities envisaged in the order, neither the former SFRY was circumvented. Although the creators of the Constitution of 1963 opted for the title "proposal for initiating a procedure for protection of rights and freedoms", it was essentially a constitutional complaint. Unlike the first, the second Socialist Constitution of 1974 totally omitted this competence, which was restored in the constitutional systems of the equal members of the SFRY by the constitutional adopted after the dissolution. Regarding the other republics, after the adoption of the Constitution in 1991, the Republic of Macedonia opted for an unpopular name with a rather limited capacity "request for protection of human rights".

Although a long list of countries that introduced a specific model of constitutional rights protection before an institution that does not bind into the basic understanding of the principle of separation of powers, an authentic method of work that slowly but surely turns into the core competence of the constitutional judiciary, however, there are states that, from various motives (primarily political and ideological), have decided to omit from the demarcated scope of work of this collective state 
body. This list of countries includes Italy, Romania, Armenia, Moldova, Ukraine, Luxembourg and others.

\section{LEGAL REMEDY OR LEGAL MEANS}

The diversity of names, the witty nature of the format and the scope of its essence, tailored to the ambience, the historical, social and political-legal circumstances, have contributed to the constitutional appeal to develop fruitful discussions about whether it is basically a legal remedy or a remedy. The answer to this question, apart from the place in the legal system of the constitutional court, depends on the determination of its basic features.

Firstly, the constitutional complaint from the aspect of the active identity is rightfully available (except with certain exceptions ${ }^{2}$ ) to individuals and legal entities when they were violated by any state constitutional right by an act or disregard of state authorities. In this direction, the submission of a constitutional complaint is related to the principle of disposition. According to this principle, the party suffering the violation depends solely on whether it will decide to institute or not to institute an authentic constitutional dispute which will require the protection of human rights through a constitutional prism. It is a discretionary right of the holder of individual constitutional values, and not a separate court law. This principle, in turn, completely excludes the constitutional court from entities carrying the active process legitimacy, because in its work the basic principle is nemo iudex ex officio, which supports the principle of official principle-allowing for the completion of the procedure even when its initiator is canceled, but this is valid for the regular court procedure, and not for the procedure for seeking protection of human rights initiated before a constitutional court. Secondly, its range is limited by the scope of the individual rights that it covers under the cover of the protection. A natural or legal person who suffers a violation from a written act of a public authority may invoke only the right that is placed in the content of the highest act, but not the lawfully violated rights. Thirdly, a legal act that is found to be "guilty" and required to be "tried" must be a sole individual act by which it is decided in a concrete and mterial manner on certain rights or obligations. Moreover, the subject matter of a judgment can only be an act adopted in a procedure, regardless of whether it was conducted against a private person or against a state authority. Fourth, the constitutional court's subsidiary position must be supported by investing the constitutional complaint. This subordinate status with regard to the judicial power when it comes to ensuring the protection of human rights protection in the first place, the constitutional court acquires with the constitutional clause for the cumulative fulfillment of two conditions: first, obligatory prior exhaustion of all regular or extraordinary legal means (depending

2 Germany envisages a separate modalities of communal complaints available to municipalities to protect constitutional competences when they are confiscated or their capacity is limited by a competent public authority. 
on the legal system ${ }^{3}$ ), which implies the validity of an appeals attack; secondly, the constitutional complaint should be submitted to the constitutional court within the prescribed legal or constitutional deadline. In terms of subsidiarity, the subject matter of the constitutional complaint may be only individual acts that carry the title of the res iudicata, a judgment item. Fifth, regardless of whether the act that is subject to a separate constitutional-court investigation initiated by a constitutional complaint is a product of a private lawsuit, the procedure before the Constitutional Court in relation to this issue is transformed into a procedure in which, on the one hand, a private subject is the holder of the right-the initiator, and on the other hand, a private party, which is a condition for running the regular litigation, is replaced by the specific legal position determined in a form of verdict whose content is attacked in a legal way. In this respect, the procedure following a constitutional complaint allows deviation from the principle of hearing the parties, audiatur et altera pars. Sixth, the decision made after a constitutional complaint in a certain manner and in a measure of a measure becomes an obligation novatio necessaria, because regardless of the nature of the position to be brought by the constitutional court on the issue concerned, there is an obligation that is of such character that requires the unimpeded fulfillment of his decision. Seventh, the constitutional court has no right to examine and evaluate the correctness of the established factual situation when the subject of the constitutional complaint is a decision passed by a regular court. In such cases, the constitutional court is absolutely limited in its actions, accepting the allegations set forth in the constitutional complaint can only lead to the adoption of a decision requiring a repetition of the procedure from the body that is the last in the hierarchy of the judicial power. More precisely, if the constitutional court would have the power to allow him to change the decision taken in a regular court in a mature way, in such a case not only openly deviates from the accepted three-level structure of the judicial power, but in no case the concrete decisions of the highest a court in the country does not have the property res iudicata. Under such circumstances, only the individual pronouncement of the constitutional court acquires such an epithet. In this respect, the Constitutional Court has no competence to examine nor the proper application of the substantive law. Eight, while the period of the constitutional court's ruling expires, the consequences that a decision is being challenged can not be stopped. But in practice, there are systems (eg. Serbia) that have opted for an intermediate solution, or the so-called. interim measures. In this regard, if the submitter together with the constitutional complaint submitted to the Constitutional Court a proposal for "postponing the execution of the individual act or action which is the reason for declaring the constitutional complaint ..., the Court may do so, but under the following circumstances: first, if the execution of a single act or action causes irreparable damages after the submitter of the constitutional complaint; secondly, if the postponement of an individual act or action is not contrary to the public interest, nor would it cause greater harm to third parties with their

3 Exhaustion of regular legal remedies: Austria, Germany, Spain, etc., while the exhaustion of regular and extraordinary legal means is provided in: Croatia, Serbia, Montenegro, BiH, Czech Republic, etc. 
delay"4. The Law on the Constitutional Court of Serbia prescribes the obligation to approve the postponement of the execution only if the specified conditions are met cumulatively. The ninth, in accordance with the principle of disposition and the right of the party concerned submitting the constitutional complaint, through the quality of the alleged allegations forming its structure, depends on which side the attention to the decision-making of the constitutional court will be directed. Moreover, in contrast to the normative control of the overall incentive right where it is allowed (for example, Macedonia), the constitutional court exceeds the framework set by the initiator of the procedure and widens the field of examination and other norms that are not initially referred to as suspicious constitutionality, it is not allowed in the procedure after a constitutional complaint. The tenth, the opening of the individual act that is subject to review from a constitutional point of view permits the constitutional complaint to be provided with partial character of an extraordinary legal remedy, due to the partial review of the impugned decision. Eleventh, the legal effect of the decision taken in the procedure for the protection of individual constitutional rights is limited capacity, it acts solely on the affected party inter partes, with the potential to expand its activity with the character erga omnes if after the completion of this procedure a special constitutional a dispute to control the general act which is the legal basis for the adoption of the impugned decision. Twelve, if more procedural means for the protection of constitutional rights with similar or identical circumstances of factual and legal arguments are submitted to the constitutional court, the adoption of one decision will mean that the other cases are completed in a more substantive manner.

The final answer to the question whether the constitutional complaint is a legal remedy or a remedy can not be obtained only by stating its basic features. The answer to this question in many respects is also dependent on the place that is given in the legal system of the constitutional court by the constituent, whether it is placed in the system as a separate fourth branch of power or an inter-state, or its position is located in classical three-part division, in accordance with the principle of separation of powers, but in the branch representing the judiciary, as a special branch within the framework of a global picture of the organs of the national judiciary (eg Germany). Where the first model is applied the answer is clear, the constitutional complaint is a legal remedy, it separates the constitutional court from the global context of the judiciary, while its position assigned to the second type of legal systems adds the prefix of the remedy, and therefore it is not surprising that most German theorists tend to define the constitutional complaint in that way. The German example of an initial procedural mechanism for protecting the fundamental rights in terms of its final definition opens another dilemma, and that is its final name, is it right to call a constitutional complaint or a constitutional complaint.It seems that this subsidiary process instrument in Germany is better to carry the name constitutional complaint, rather than a constitutional complaint. This position is justified by two facts regarding the procedural actions that the initiator of the procedure has the

4 Пајванчић, М., Уставно судска заштута људских права, Правни факултет Нови Сад, Нови Сад, 2011., p.131-132. 
right to take. Firstly, the holder of the privilege, in legal proceedings, to address the Federal Constitutional Court when initiating the proceedings, acts as a plaintiff who "submits evidence and sets out claims whose validity should be determined" Secondly, "the possibility of contradicting the procedure is not excluded, in fact in a number of cases this procedure is being contradictory"

Basically, if the constituents opt for a complex term determinant, a constitutional complaint may arise of some procedural problems, because the first association, when using this title, is that reaching after its identity will mean a request from the constitutional court for first instance, which would lead to the takeover of the jurisdiction of the regular judicial authority, even though its substantive content is in good measure deviating from the lawsuit filed before the regular court. For example, the procedural rules that shape the procedure after the constitutional complaint do not contain an obligation for the state body to compulsorily submit a response to the lawsuit, the deviation of which would involve the adoption of a final decision with an obviously different character. When speaking of the name "complaint", the first association is that several important principles, such as the principle of two-step procedure, the principle of hearing the parties, rules that are not inherent in the constitutional complaint, the basis of the constitutional court lies in the impossibility of a second instance trial, regardless of whether it is an internal body with appropriate competences, or is it a particular state body positioned outside the constitutional court.Hence, an appropriate and correct choice narrows around these two notions, but several significant segments are detected that allow the choice of the name "constitutional appeal" to come nearer. The basic association when using the term constitutional complaint is that a decision has already been taken by a competent authority. In that direction, the actions of the constitutional court in this case does not mean clarification in the initial phase, the first degree.

The decision required by the constitutional court implies that the said case has already been brought to the stage of complete absence of the regular institutional path provided for this type of legal dispute, hence the length of the proceedings before the constitutional court can only postpone the principle of res iudicata.

From that aspect, when these facts are taken into account, and when the choice of the name of the process institute is reduced to a constitutional complaint, in relation to its other side, the theoretical determinant is the most appropriate "legal remedy", although its nature does not completely overlap nor with this name, but is more acceptable and can more closely determine his character. Basically, this is a process law institute with a mixed, or hybrid nature, the basis of which is the characteristics of the term "legal remedy", and it has been supplemented with upgraded, but to a limited extent, elements of the term "legal remedy". From the term "legal remedy", segments from the regular legal action have been taken, which is the established right to initiate an individual legal procedure and the authorization

5 Schwabe, J., Izabrane odluke Njemačkog saveznog Ustavnog suda, Jubilarno izdanje, Fondacija Kondar Adenauer, 2009., p. 47.

6 Ibid., p. 47. 
of the constitutional-judicial body for the implementation of a certain form of regular judicial review but limited only permitting review of the impugned individual act in terms of constitutional norms. Applying the name "legal remedy" in relation to a constitutional complaint implicitly implies that its application has not been placed in an identical position, as is the complaint before the regular judiciary. A regular appeal is filed against an unlawful judgment, in contrast to extraordinary legal remedies that are pronounced precisely against effective court judgments, but under exceptional strictly signed legal conditions "when the regular legal remedies can no longer be submitted, in order to be re-established reviewed by the competent court ${ }^{7}$.

Finally, the common elements of the constitutional complaint with the regular complaint and appeal are perceived through several important rules: the principle of disposition, the assessment of the admissibility of the submission, the nemo iudex ex officio, the right to initiate the procedure, the limitation of the active process legitimacy only on subjects of private law, examination of procedural assumptions, the inability to expand the capacity of constitutional complaint during the procedure, etc.

\section{CONSTITUTIONAL COMPLAINT IN THE REPUBLIC OF MACEDONIA}

The 1991 Constitution of the Republic of Macedonia, apart from the name of the procedural means for the protection of subjective constitutional rights, made a mistake in terms of its capacity. However, despite the fact that the Constitutional Court has wide jurisdiction, it is a serious remark that in a direct and unequivocal manner it establishes protection of only three of the total of 41 basic freedoms and rights guaranteed by the Constitution.

Under the direct legal protection are the freedom of conviction, conscience, thought and public expression of thought, political association and action, and prohibition of discrimination of citizens on grounds of sex, race, religion, national, social and political affiliation (Article 110, line 3). From the foregoing it is clearly noted that the Constitution does not establish protection for any social or cultural right of the citizens. The fact that in the constitutional court practice for a period of 25 years of independence, the Constitutional Court has passed only one verdict related to the protection of the rights and freedoms guaranteed by the Constitution ${ }^{8}$.

In an attempt to overcome the restrictive approach to existing legal protection, on July 16, 2014, the Parliament, by a two-thirds majority, positively pleaded with the Government's proposal for a package of constitutional amendments, which, inter

7 Тубић, Б., Локални правни лекови у пракси Европског суда за људска права, Зборник радова Правног факултета у Новом Саду, 3/2006., p. 415.

8 That's decision number U.br. 84/09 of 10 February 2010, which established a violation of the right to political action. 
alia, in the Draft Amendment XXIX ${ }^{9}$, stipulates the incorporation into the system precisely constitutional complaint. Such a concept of constitutional appeal contains several advantages, but at least double the problems that it will create in practice if the procedure for amending the Constitution is completed.

Regarding the advantages, it is a welcome that it is for the first time prescribed a constitutional complaint Until now, the Republic of Macedonia is the only contemporary state with an accepted Euro-continental legal system that does not have a constitutional basis for passing a Law on the Constitutional Court, the request for protection of human rights under the justification of regulatory autonomy of the Constitutional Court was regulated by its Rules of Procedure to the legal institute and its importance is emphasized by granting a constitutional status. But the move has a major disadvantage, allowing the Constitutional Court, independently with a third-party legal norm, to regulate this issue gives it the right if it considers that it should no longer act on this part of the constitutional norms, by a majority of votes from the total number of members ( 5 votes) to remove this provision. Thus, the application of indent 3 to Art. 110 of the Constitution will be completely suspended. In such circumstances, if it is known that the decisions of the Constitutional Court are inviolable, supported by the knowledge that there is no procedural instrument that would allow another state body to influence this decision of the Court, it is more than clear that the justification of the autonomous an area for regulating specific questions of a constitutive character, is unsustainable. Further, for the first time this one The draft amendment determines the list of authorized entities using the terms "physical" and "legal entities". The current regulation in this section is extremely irregular. The Constitution allows the right to initiate the proceedings of every "citizen", but not to every "man". The exclusion of certain persons from the circle of legal entities that will dispose of the process legitimacy is basically discriminatory, because it does not allow to call for legal protection before the Constitutional Court and persons who have not acquired the status of "citizens" in the society.

9 The text of paragraph 1 of the proposed amendment reads as follows: decides upon a constitutional complaint filed by a natural and legal person, declared against an individual act or action by a state body, a unit of local self-government or a holder of public authorizations that violate the freedoms and rights of the individual and the citizen, namely: the equality of the citizen in the freedoms and rights, regardless of sex, race, color of the skin, national and social origin, political and religious beliefs, property and social status, right to life,the prohibition of torture, inhuman or degrading treatment, punishment and forced labor, the right to human freedom, the right to presumption of innocence and a fair trial, freedom of belief, conscience, thought and public expression of thought, freedom of speech, public performance, public information and the free establishment of public information institutions, the freedom and inviolability of letters and all other forms of communication, the security and secrecy of personal data, freedom of religion, freedom of association, etc. the gathering and expression of public protest, the respect and protection of the privacy of personal and family life, the dignity and reputation, the inviolability of the home, and the right to free movement, when other domestic regular or extraordinary remedies are exhausted or not provided for their protection. Paragraph 2 shall read: decide upon an appeal filed against a decision of the Judicial Council of the Republic of Macedonia for election, dismissal, or other pronounced disciplinary sanction of a judge or president of a court. Paragraph 3, in addition, regulates the right to appeal in the following manner: it decides on an appeal filed against a decision of the Public Prosecutors Council for the election, dismissal or other pronounced disciplinary sanction of a public prosecutor. 
Apparently, the positive side seems to be the elevation of the constitutional level to the position of the Constitutional Court with regard to the protection of individual rights through the requirement for prior exhaustion of all regular and extraordinary legal remedies before the victim of acts or acts of public authorities to acquire the right to addressed the Constitutional Court.

And so, here the list of positive aspects of constitutional complaint is exhausted. The other effects that it produces, as it is now foreseen in its content, are all with extremely unfavorable consequences that would create a violation of the principle of legal certainty, but also with a potential danger of creating inter-organ tensions in their mutual relations.

In addition to the constitutional law, this draft law in paragraphs 2 and 3 introduced the regular complaint, a moment that will definitively remove from the base the basic way of acting of the Constitutional Court, which is stipulated not only by the Constitution of the Republic of Macedonia, but drastically deviates from the theoretical conception of its creators (Kelsen, Merkel). Thus, in comparison with the organic laws (Law on the Judicial Council and the Law on Public Prosecution), but also with the Law on Administrative Disputes, these two paragraphs of the Draft Amendment create in the order the existence of parallel legal remedies and legal procedures, in the first case of the organic laws, while completely excluding certain provisions from the Law on Administrative Disputes on their reference and use as a legal basis for the protection of violated rights, in the second case. Regarding the Law on the Judicial Council, the introduction of parallel remedies and legal proceedings is detected in Art. In accordance with this provision, a regular judge is guaranteed the right to initiate a procedure before a special collective body called the Council composed of the two judges before the Supreme Court of the Republic of Macedonia, when a decision was reached by the Judicial Council for dismissal or disciplinary measure. Hence, if according to the Macedonian positive law, the decision abolishing or confirming the decision of the Judicial Council is final, and if with such a status against it it is not allowed to submit another legal remedy for defamation of the content, then what is the logic to violate this position by prediction of a constitutional provision of this kind. Additionally, the persistence of the regular appeal in the work of the Constitutional Court will allow in practice a series of complications and combinations in relation to this issue. Namely, given the fact that the original idea of this paragraph of the Draft Amendment introduces a regular, not a constitutional complaint, it practically means that after the exhaustion of the procedure regulated in the Law on the Judicial Council, the applicant will be entitled, after the eventual failure to demolish the decision of this body adopted within the procedure provided for in the same law, to submit to the Constitutional Court a content identical legal remedy. In this section, the question arises whether, if the Constitutional Court adopts a decision affirming affirmatively with regard to identical allegations that the Council has adopted a decision with negative implications for the complainant, its or the Council's decision will be applied, given the fact that it is not a matter of proceeding against the decision, but separate and different from that set out in Art. 96 of the Law on the Judicial 
Council. Additional complication is made by the fact that the title "legality" of the decisions adorns the end of both procedures. Does this mean, moreover, that the applicant will have the right to independently decide which of the competition authorities will submit the complaint given the aforementioned fact that it is a matter of separate legal proceedings. The particular combination of legal norms gives the applicant another solution. In principle, it is not forbidden for the applicant to start and run the two proceedings in parallel with the various competent authorities for the same legal matter. In such a situation, if both competent authorities, the Constitutional Court and the Council declare themselves differently, one positive positively negative, the applicant will have full legitimacy to decide independently which decision he will adhere to. On the other hand, the regular appeal combined with the subsequent application of the constitutional complaint leads to violation of the basic characteristic of the decisions of the Constitutional Court.

The violation of the term "finality and enforceability" of the Constitutional Court's decision is again a consequence of the regular complaint that introduces the aforementioned draft amendment in the work of this state body. Namely, unlike the one-degree procedure after the decision reached before the Supreme Court, as is now predicted by the Law for the Judicial Council, the institutional conduct before the Constitutional Court will get a real basis. $f$ the applicant institutes proceedings before the Constitutional Court and is not satisfied with the "first instance" expressed in a decision, he will have a constitutional legitimacy to file an appropriate constitutional complaint to the same authority, invoking a violation of a right specified in paragraph 1 of this amendment. In addition, unlike the second degree before the regular trial courts, this two-instance will cause re-clarification following the same legal claims of the same current composition.

Almost similar are the consequences when it comes to the Law on Public Prosecutions. When it comes to the Law on Administrative Disputes, here the Draft-Amendment leads to the other extreme, it almost neglects or minimizes the procedure before the administrative courts. In that direction, Articles 2 and 55 of the Law on Administrative Disputes are suspended, legal norms that guarantee the right to a regular institutional route initiated through an administrative dispute. Article 2 precisely regulates the assessment of the legality of the individual act for the appointment and dismissal of a holder of a public office, while Art. 55 is dedicated to the protection of human rights and freedoms guaranteed by the Constitution when they are violated by an individual act, and no other court protection is provided. Practically, in relation to the Constitutional Court, this article regulates its subsidiary competence, which is fully in line with its position when it comes to the protection of human rights. This stems from the proceedings before the Council established by the Supreme Court.

In comparison with the comparative experiences of the states that have introduced a constitutional complaint, it can be noted that the solution envisaged in the case of the Republic of Macedonia does not closely follow the existing definitions devoted to this initial mechanism. Thus, instead of a short constitutional provision that 
would only pave the way for detailed regulation through appropriate legal norms, the proposers of this amendment decided to enormously taxify the rights for which a special form of legal protection is guaranteed, creating only a legal illusion that they are working for a quality constitutional framework. But, on the contrary, in this case it is a matter of limiting the legal protection. The proposer of this constitutional amendment in a fictitious manner only carries out a breakdown of the complex content of a particular right.

The above legal illusion of the number of protected constitutional rights is complemented by facts deriving from two legal sources, the Constitution and the European Convention for the Protection of Human Rights and Freedoms. For example, freedom of speech, public appearance, public information and the free establishment of public information institutions are segregated segments that are part of one single right envisaged in Art. 11 of the Convention. The ban on punishment and forced labor is only part of Art. 4. Partial protection is also provided for the inviolability of letters and all other forms of communication, respect and protection of the privacy of personal and family life are part of a single right of art. 8. It is a defamatory right for which the same legal basis is envisaged. Protection of the inviolability of the home and security of secrecy of personal data are still two separate rights that disassemble the legal concept set forth in Art. 8. Furthermore, the freedom of religion and the freedom of conviction, conscience, thought, and public expression of thought are two parts which form art. 9. The freedom of association and the right to gather and express public protest are laid down in Art. 11.

At the national level, at the constitutional level, the situation is as follows: the breakdown of rights is carried out by identical order, dignity and reputation, personal and family life. 25, torture, inhuman behavior and forced labor are part of a constitutional norm, Art. 11 art. 2 and 3, freedom of speech, freedom of thought, public appearance and the right to access information, Art. 16 th. 1, 2, and 3. The draft amendment lists them as special rights, but in essence it is a single multi-component right. Then, the presumption of innocence, Art. 13 and 14, the confidentiality of the letters and the secrecy and security of personal data, Art. 17 and 18. The remaining rights are given in constitutional norms as stand-alone legal sources. The right to equality and equality (prohibition of discrimination) Art. 9, the right to life Art. 10, the right to freedom, Art. 12, Freedom of Religion Art. 19 and Amendment VII, the right to associate Art. 20 tb. 1 and 2, the right to public protest, Art. 21, the inviolability of the home Art. 26 and freedom of movement art. 27.

Despite the fact that these rights are drawn from two sources, that is, their legal formulation exists in two legal documents, the Constitution and the European Convention, however, it is clear that the constitution-maker in forming the structure of this proposed amendment in paragraph 1 was guided by the domestic constitutional right. Hence, it is unclear why it is envisaged initiation of the constitutional complaint and the right to a fair trial, that is, the right to a fair trial. If for the remaining listed rights there are separate constitutional members, that is, an appropriate established textual form at the constitutional level, regardless of the fact that most of those 
rights are part of an identical article, and on the basis of the stated fact that the observer was still guided by the domestic constitutional regulation, a question arises, according to which the content of the Constitutional Court when it sets the standards for protection of the right to trial within a reasonable time, is a segment of this complex right. Although in accordance with the applicable constitutional norms the Constitutional Court has the right to refer to the international ratified agreements when deciding on a particular legal matter, however, the basic remark for its work thus far refers precisely to the restrictive interpretation of the norms of international law, and in particular this approach is established precisely in the built relationship with the European Convention. This is all the more so that the Law on Courts provides for a procedure before the highest court in the state precisely for the protection of this special right. Given this, it is clear that at this moment it is not a constitutional right, but a legal procedural right protected in a material way through an appropriate one-sided procedure. It is precisely in the provisions of the law on the organization and work of the judiciary that the constitutional inconsistency concerning the right to a trial within a reasonable time is covered, the Supreme Court is legally in the obligation to follow the established practice of the Human Rights Court regarding this issue.

\section{CONCLUSION}

The significance of the constitutional complaint from today's point of view is detected in terms of the number of cases processed by the constitutional courts. Hence, according to the competences codified by the legal system of Germany, the constitutional complaint is convincing in the first place. The competence for the resolution of cases filed on the basis of the constitutional complaint is increasingly imposed as a basic constitutional-judicial function.

The number of sentences before the ECtHR is placed by the Republic of Macedonia in the group of countries that are considerably more numerous (Turkey, Ukraine, Russia, etc.). Most often, the basics that are cited when establishing a contact with the Human Rights Court are the absence of a trial within a reasonable time, as well as the lack of an effective remedy at the national level for resolving specific disputes. In the direction of reducing this negative trend is the attempt to implement the constitutional complaint. But its shape and capacity proposed in this way does not solve the problem at hand, on the contrary it encourages its propagation. For this reason, the only acceptable solution is the complete withdrawal of this draft amendment. 


\section{USTAVNA TUŽBA - PROCEDURA ZAŠTITE LJUDSKIH PRAVA - S POSEBNIM OSVRTOM NA USTAVNU TUŽBU U REPUBLICI MAKEDONIJI}

U tekstu autor istražuje povijesne aspekte ustavne tužbe analizira genezu njene implementacije u pravne sisteme, prije svega u državama zapadnih demokracija. Autor pritom nastoji naći odgovor na pitanje je li ustavna tužba pravilno označena kao pravni lijek ili lijek općenito. Treba imati u vidu da se definitivni odgovor daje i konačno biva određen od strane Ustavnog suda u sistemu državne vlasti. Posebna pažnja je posvećena pokušaju impklementacije ustavne tužbe u pravni sustav Republike Makedonije. U kratkoj analizi autor izlaže kritičnu analizu konstitutivnih elemenata ustavne tužbe kako je predviđa Nacrt promjene Ustava Republike Makedonije. Posebna pažnja je posvećena paragrafima 2. i 3. Nacrta Amandmana XXXIX sa stajališta negativnog utjecaja kojeg on ima na poziciju Ustavnog suda.

Ključne riječi: ustavna tužba, pravno sredstvo, amandman na Ustav, redovna tužba 